\title{
SLOT TIME CAPACITY IN PEAK HOUR AT SOEKARNO-HATTA INTERNATIONAL AIRPORT
}

\author{
Adnan Arya Wicaksana ${ }^{1}$, Fikri Maulana Effendi², Tito Warsito ${ }^{3}$ \\ 1. STMT Trisakti, 2. STMT Trisakti, 3. STMT Trisakti \\ $\bowtie$ Corresponding author: Adnanaw57@gmail.com
}

\begin{abstract}
In early 2015, Soekarno-Hatta International Airport was one of the airport that nominated as the busiest in the world in 2014. Soekarno-Hatta was ranked 12, with the number of passenger \pm 59.4 million per year, which is around 162 thousand passengers come and leave the airport every day. Month by month the traffic tends to rise. Gradually, the traffic growth will be an opportunity for Indonesia, but it can be a threat if the traffic growth is not handled properly. The purposes of this research are to calculate the true capacity of runway with 2 runways owned by SoekarnoHatta International airport and predict the traffic growth happened using queue theory and forecasting methods. The result is to shows that slot time perhour has beyond the number of capacity and increasing the amount of traffic would affect the slot time significantly. So runway utilization shows that adding new runway is one of the methods to cope of traffic growth currently.

Keywords: Soekarno-Hatta, slot-time capacity, add runway, traffic growth, queue
\end{abstract}

\section{Introduction}

Soekarno-Hatta International Airport (SHIA) is one of a hub airport in Indonesia. Soekarno-Hatta is the busiest airport in Indonesia, SHIA is $21^{\text {st }}$ busiest airport in the world (Based on Airports Council International's (ACI), with 54,969,536 flow of passenger in 2016. Soekarno-Hatta runway consists of 2 runway, using direction $07 \mathrm{R} \& 25 \mathrm{R}$ and $07 \mathrm{~L} \& 25 \mathrm{~L}$.

Soekarno-Hatta uses two runways that able to serve more than 30,000 traffic in a month. It also always increases every year. That situation pushes Soekarno-Hatta to develop the airport. Last year, terminal 3 ultimate was officially opened. With these development, passenger flow increases, but how about traffic movement?

According to IM (Instruksi Mentri) 16 in 2017,Soekarno-Hatta International airport only provides and serves 80 movements for regular flight and one movement for irregular flight per hour, but in reality it serves 84 aircraft movements per hour. It means more than the slot time allowed by regulation. This paper investigates traffic movement with the traffic growth that happened at Soekarno-Hatta International airport (SHIA). The Analysis data is obtained from national air Navigation Company to show traffic growth at 
SHIA, and the purpose is to predict when SHIA should finish building $3^{\text {rd }}$ runway.

\section{Background}

In early 2015, Soekarno-Hatta International airport was one of the airports nominated as the busiest in the world in 2014. Soekarno-Hatta was ranked 12, with the number of passenger \pm 61.2 million per year, which is around 173 thousand passengers come and leave the airport every day.(Ricardianto \& Rifni, n.d.)

Runway is an important point to help aircrafts in take-off and landing. A runway can normally be used in both directions, and is named for each direction separately: e.g., "runway 33" in one direction is "runway 15" when used in the other side. The number of runway shows the degree of direction (e.g. runway 15 means facing $150^{\circ}$ of north or runway 27 means facing $270^{\circ}$ of north). The runway was made with considering wind direction and the number is like in the clock if the runway leads to the north or $0^{\prime \prime}\left(0^{\circ}\right)$ it means behind the runway is $18^{\prime \prime}\left(180^{\circ}\right)$.

Slot time is a capacity owned by an airport and it is allocated by a coordinator to manage departure and arrival operations of an airline on a specific date and time. According IDSC (Indonesia Slot Coordination), which refers to guidelines of IATA (International Air Transport Association) slot time is defined as a permission to operate at a scheduled time of departure and arrival in a specific date and time at an airport (IATA, 2011). For slot allocation all parameters that will be taken into account are runway, taxiways, aircraft parking stands, gates, terminal capacity (e.g. check-in and baggage delivery), and enviromental constraints e.g. night restrictions, etc. So the researchers assume from the theory above that slot time is a permission given by the coordinator for a planned operation to use the full range of an airport infrastructure required to arrive or depart at an airport on a specific date and time. Slot time is the availability of gate/runway and schedule, and airport speciication, airport facilities, and airport.(Setiawan, Jakarta, \& Majid, n.d.) Queue is a common situation in life where consumers wait in front of the counter to get a turn of service or service facility. Lines of cars waiting to take 
turns paying for highway, people on vacation waiting to get into zoo, and customers waiting for transactions at the bank are some examples of queuing situations. Queue is a waiting situation when there are number of physical entities (visitor) are waiting to receive service from a facilitator (service provider), so they must wait for while in line to get to be served (Heizer, 2009). Queues are the science of queuing pattern, there are people or items in the line waiting to be served or how the company can determine the best time and facilities to serve customers efficiently. (Tanjung, 2003). According to the definition, it can be concluded that queue is a common situation where the consumers wait in line in order to be served by the service provider.

\section{Multi-Channel, Single-Phase}

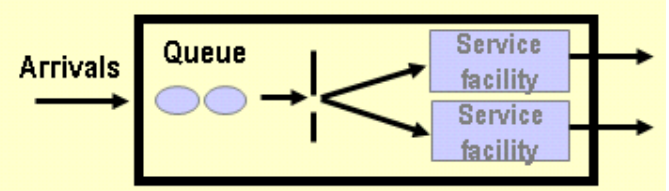

Figure 1. Multi-channel, Single-Phase Models Source: (River, 2004)

1) The probability that there are 0 people in the system (there are 0 customer

system).

Po $=\frac{1}{\left[\sum_{\mathrm{n}=0}^{\mathrm{M}-1} \frac{1}{\mathrm{n} !}\left(\frac{\lambda}{\mu}\right)^{\mathrm{n}}\right]+\frac{1}{\mathrm{M} !}\left(\frac{\lambda}{\mu}\right)^{\mathrm{M}} \frac{\mathrm{M} \mu}{\mathrm{M} \lambda-\mu}}$

2) The average number of customers in the system

$\mathrm{Ls}=\frac{\lambda \mu(\lambda / \mu)^{\mathrm{M}}}{(\mathrm{M}-1) !(\mathrm{M} \mu-\lambda)^{2}} \operatorname{Po}+\frac{\lambda}{\mu}$

3) The average time a customer spends in a queue or on a queue served (in the system)

Information:

$$
\mathrm{Ws}=\frac{\mathrm{Ls}}{\lambda}
$$

4) The number of people or average units waiting in the queue $\mathrm{Lq}=\mathrm{Ls}-\frac{\lambda}{\mu}$ 5) Average time spent by a customer or unit for waiting in queue

$\mathrm{Wq}=\frac{\mathrm{Lq}}{\lambda}$

6) Runway Utilization

$$
\rho=\frac{\lambda}{\mathrm{M} \mu}
$$


- $\mathrm{M}$ : The total of available channels.

- $\lambda$ : The total average of arrival per unit time

- $\mu \quad$ : The total average served per unit time at each channel

- $\mathrm{n}$ : The total customer

- Po : The probability that there are 0 people in the system
- Ls : The average number of customers in the system

- Ws : The average time a customer spends in a queue or on a queue served (in the system)

- Lq : The number of people or average units waiting in the queue

- $\mathrm{Wq}$ : Average time spent by a customer or unit for waiting in queue

\section{Method}

Type of data that used in this research is data qualitative and quantitative. Qualitative data is not about the number or everything related with statistic meanwhile the form of explanation concerning various thing pertaining with the matter this research, as for example any perception of each figure of variable like the effect of traffic growth and relation of each variable. Quantitative data is data that shaped in number that can be counted and the source is actual fact based on reality such as the number of traffic growth, peakhour, peak day with the process forecasting through SPSS, also using queue theory to analyze runway utilization. Descriptive comparative is methodology research that have the purpose of "comparing" this method used to compare sample of aircraft movement between using 2 runways and 3 runways.

The source of data was secondary data. Secondary data is data which is directly obtained from the historical data. It was also obtained through discussion with AIRNAV INDONESIA employee, and from company archive itself.

\section{Discussion \& Result}

A. General Description about Traffic at Soekarno Hatta International Airport The biggest hub airport in Indonesia is Soekarno-Hatta International airport which range of $18 \mathrm{~km}^{2}$ and has two main parallel runways. Each runway, which 
length is $3.66 \mathrm{~km}$, is connected by two taxiways cross. To support the access reach ramp handling area (aircraft parking stand) the passenger will pass the terminal first and prepare all requirement of a procedure of pre-flight and post flight like check in first when come to airport, body check and goods check (security check point), etc. Terminals provided by Soekarno-Hatta International airport are three main terminals, such as terminal 1 for domestic airlines, there are Lion air, Sriwijaya air, Express air airlines, Batik air, Trigana air, Transnusa, Kalstar, and Citilink Indonesia; terminal 2D \& 2E are filled by international airlines which operate in international routes; terminal $2 \mathrm{~F}$ has airlines like Sriwijaya air, NAM air, and Indonesia Air Asia domestic destinations, and the last terminal 3 is currently resided by Garuda Indonesia airlines for both domestic and international destinations. There is also a transport terminal for domestic cargo and international cargo. (Yuliana, 2015)

\section{Chart 1. Aircraft Traffic Movement at Soekarno Hatta International Airport on January 2015 - September 2017}

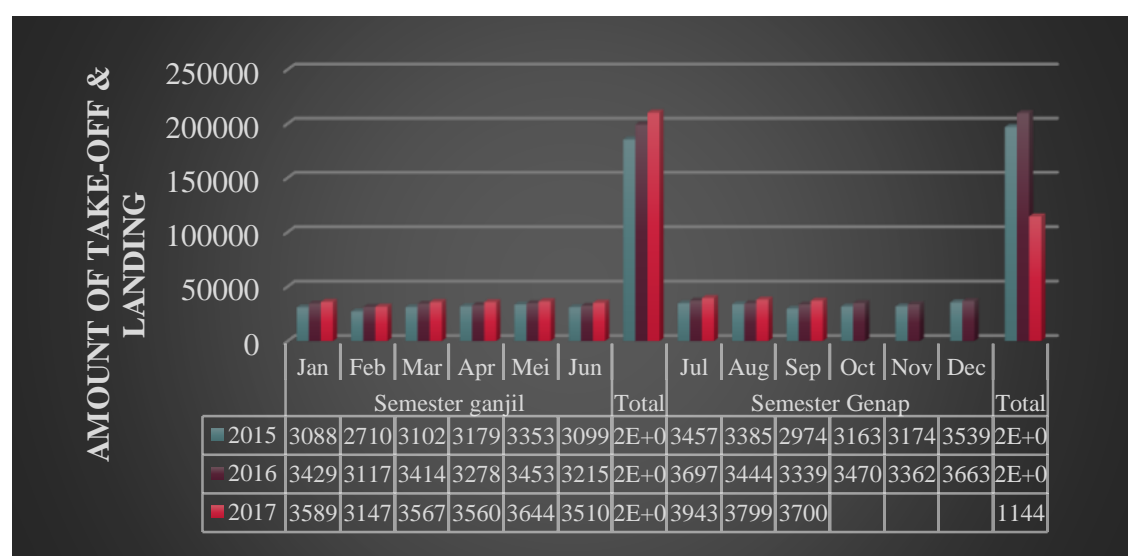

Source : (Airnav Indonesia, 2017)

From two runways owned by SHIA, the researchers counted all of traffic done by the airlines, the amount consisting of the total take-off/landing or departure/arrival of both domestic and international flights in chosen period which was on January 2015 until September 2017. 
Table 1. JATSC Report Related Amount of Traffic, Peak Day, and Peak Hour on January 2015 - September 2017.

\begin{tabular}{|c|c|c|c|c|c|c|c|c|c|c|}
\hline \multicolumn{10}{|c|}{ JATSC Aircraft Movement } \\
\hline \multirow{2}{*}{$\begin{array}{c}\text { N } \\
\text { O }\end{array}$} & $\begin{array}{c}\text { MONT } \\
\text { H }\end{array}$ & $\begin{array}{c}\text { Traffi } \\
\text { c }\end{array}$ & $\begin{array}{c}\text { Peak } \\
\text { Day }\end{array}$ & $\begin{array}{c}\text { Peak } \\
\text { Hour }\end{array}$ & $\begin{array}{c}\text { Traffi } \\
\text { c }\end{array}$ & $\begin{array}{c}\text { Peak } \\
\text { Day }\end{array}$ & $\begin{array}{c}\text { Peak } \\
\text { Hour }\end{array}$ & $\begin{array}{c}\text { Traffi } \\
\text { c }\end{array}$ & $\begin{array}{c}\text { Peak } \\
\text { Day }\end{array}$ & $\begin{array}{l}\text { Peak } \\
\text { Hour }\end{array}$ \\
\hline 1 & Jan & 30889 & 1243 & $75 / 17: 00$ & 34295 & 1239 & $78 / 15: 00$ & 35892 & 1229 & $78 / 15: 00$ \\
\hline 2 & Feb & 27105 & 1128 & $75 / 16: 00$ & 31175 & 1169 & $79 / 09: 00$ & 31470 & 1193 & $77 / 10: 00$ \\
\hline 3 & Mar & 31021 & 1102 & $73 / 09: 00$ & 34144 & 1186 & $77 / 15: 00$ & 35674 & 1218 & $78 / 15: 00$ \\
\hline 4 & Apr & 31797 & 1157 & $75 / 16: 00$ & 32780 & 1152 & $79 / 09: 00$ & 35609 & 1271 & $80 / 12: 00$ \\
\hline 5 & May & 33530 & 1176 & $77 / 09: 00$ & 34538 & 1205 & $78 / 14: 00$ & 36448 & 1255 & $81 / 17: 00$ \\
\hline 6 & Jun & 30997 & 1154 & $75 / 17: 00$ & 32150 & 1202 & $78 / 15: 00$ & 35102 & 1361 & $84 / 10: 00$ \\
\hline 7 & Jul & 34572 & 1233 & $78 / 15: 00$ & 36972 & 1250 & $79 / 15: 00$ & 39435 & 1373 & $84 / 10: 00$ \\
\hline 8 & Aug & 33856 & 1161 & $74 / 15: 00$ & 34440 & 1162 & $77 / 15: 00$ & 37991 & 1289 & $82 / 10: 00$ \\
\hline 9 & Sep & 29747 & 1071 & $74 / 15: 00$ & 33392 & 1174 & $82 / 10: 00$ & 37000 & 1301 & $79 / 09: 00$ \\
\hline 10 & Oct & 31633 & 1106 & $73 / 18: 00$ & 34705 & 1176 & $77 / 18: 00$ & & & \\
\hline 11 & Nov & 31747 & 1157 & $81 / 15: 00$ & 33625 & 1180 & $78 / 16: 00$ & & & \\
\hline 12 & Dec & 35392 & 1246 & $78 / 14: 00$ & 36637 & 1257 & $79 / 16: 00$ & & \\
\hline
\end{tabular}

Source : (Airnav Indonesia, 2017)

The following is the example of JATSC (Jakarta Air Traffic Service Center) data which acts as air traffic service centre at SHIA that has a role to monitor the situation in an airport, starting from traffic, peak day, and peak hour. Its all be recorded monthly and could be a development analysis. From data under we have the problem where in peak hour for slot time per hour any some slot or cell with red colour its filled more than maximum capacity or more than 81 slot time ( 80 reguler flight and 1 irregular flight) .

\section{B. Slot Time Plan in Chronos with The Actual Slot Time in Operation}

Slot time is arrival and departure time schedule allocated by "CHRONOS" application and "CHRONOS" itself is a plan or target for an airline to inform the time for take-off and landing in that airport, but this slot can change in the operation. It can be influenced by demand and delay. Both will give bad impact to the airline itself if delayed because it will make a flight delayed to the next slot (if possible) or even to the next day. This application is under the management of AIRNAV Indonesia. It was established in 2015 for the aircraft movements at time/date specified, and adjusted / harmonized with the existing airport facilities or the schedule of using the facility. Slot time one of the tools to do strategic air traffic flow management. Slot time overcrowded schedule is allocated to the time or hours that still have space to movement so that the existing capacity in that airport can be used optimally. Slot time is created to resolve overload traffic movement called "peak moment", such as peak season, peak day, and peak hours. Peak season is a crowded condition that attracts people to travel to some 
destinations because there are events that only last in specific amount of time, for example religion events (Idul Fitri, Idul Adha, Christmast, and Imlek), national events (Independence day), general events (New year), etc. (Satiti, 2012)

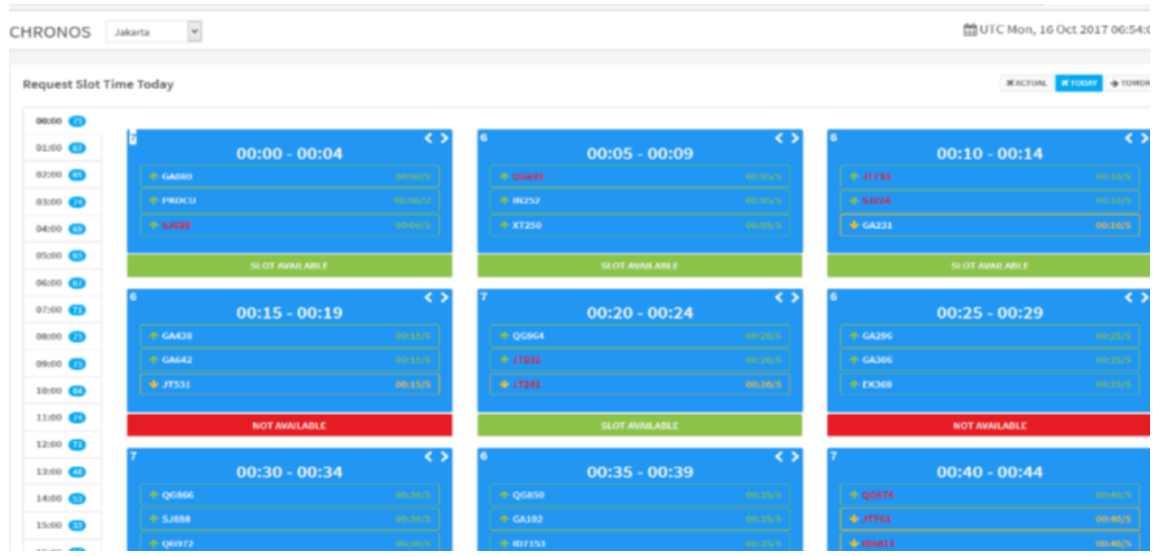

Figure 2. Slot Time Per Hour From Chronos Application Source : (ATFM, 2015)

The picture above is the slot time in chronos application on 16 october 2017. The time is in UTC (Universal Time Coordinate). Up arrow direction means departure, down arrow direction means arrival and red font means changing slot which means having slot change before.

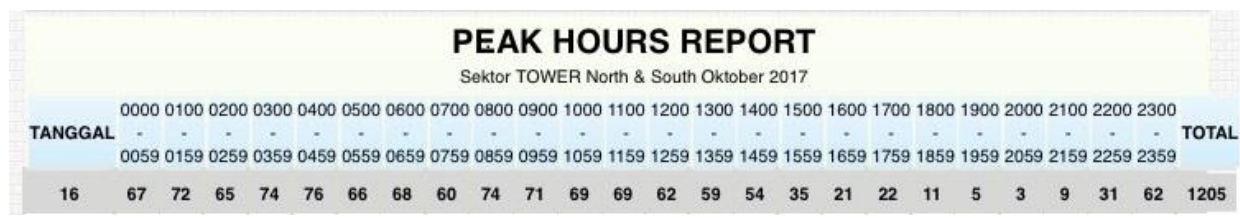

Figure 3. Slot Time Per Hour From JATSC Report

Source : (Jakarta Air Traffic Service Center (JATSC), 2017)

This picture above is the slot time in operation on 16 October 2017. It has a purpose to enable comparison between plan slot time filled by the airline in chronos with the actual slot time in operation.

Result. 
Table 2. Forecast Peak Day, Peak Hour, and Traffic with SPSS Methode

\begin{tabular}{|l|l|r|r|r|r|r|r|}
\hline \multirow{2}{*}{ Result } & \multicolumn{7}{|c|}{ Month } \\
\cline { 3 - 8 } & \multicolumn{1}{|c|}{76} & 77 & 78 & 79 & 80 & 81 \\
\hline $\begin{array}{l}\text { Peak } \\
\text { Day }\end{array}$ & Forecast & 1650 & 1658 & 1666 & 1674 & 1681 & 1689 \\
\hline $\begin{array}{l}\text { Peak } \\
\text { Hour }\end{array}$ & Forecast & 90 & 91 & 91 & 91 & 91 & 92 \\
\hline $\begin{array}{l}\text { Traffic } \\
\text { per } \\
\text { month }\end{array}$ & Forecast & 45430 & 45631 & 45831 & 46032 & 46232 & 46433 \\
\hline
\end{tabular}

The researchers describe forecast using SPSS. Traffic movement per hour in Soekarno-Hatta International airport is beyond the capacity, on the $77^{\text {th }}$ month from January 2015 the traffic movement per hour reach 91/hours, with that result we can assume traffic growth in Indonesia will keep increasing every year. Based on Ministry Instruction no.16 2017 optimally SHIA are able to serve 80 regular flights and 1 irregular flight, and maximum control aircraft movement per hour is 90 movements, but it will reduce the quality of service to guide aircraft movement. Which means with facilities and infrastructure owned and supplied, SHIA now is no longer able to serve aircraft movement for the next 5 years.

This is a forecasting. If it is seen from the graphic, any increasing seems clear and we can predict how many percents traffic increasing every month. In this scenario the researchers predicted that the increasing rates is $0.44 \%$ each month, which is in every month traffic will increase \pm 200 traffics each month, which is the facilities and infrastructure such as gates, parking stand, garbarata. The availability of runway will no longer able to serve in next 5 years. 
Chart 2. Graphic of Forecast Result

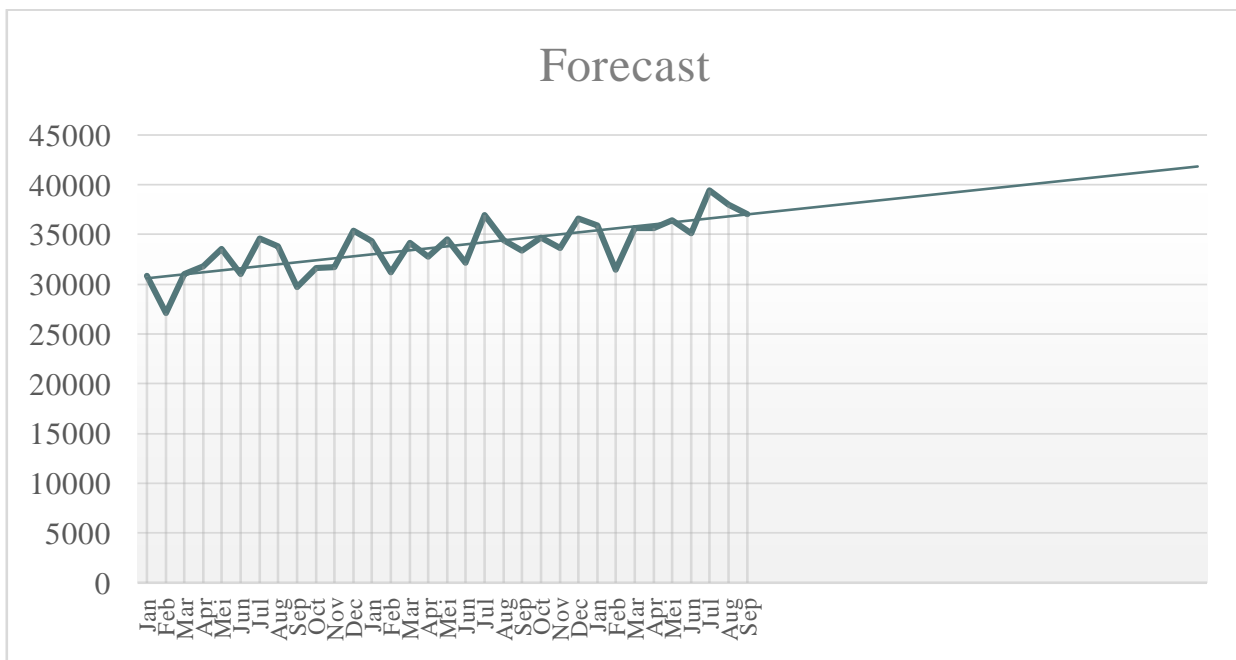

The optimal aircraft movement is 81 movements, consisting of 80 regular flights and 1 irregular flight, but the maximum movement is 90 aircraft movement per hour. With this prediction PT Angkasa Pura II should prepare to upgrade their airport. Safety awareness should be increasing. It starts from adding new facility and infrastructure to support building a new runway without disrupting the work of other runways.

The number of slot time per hour in chronos is proved that there are changes in operation. There are also increases and decreases, but mostly decreasing in operation. It is all influenced by demand of passengers and delays. If there is no passengers' request or delay happens, it will make flight delay to the next slot (if possible) or even to next day depending on the situation.

Table 3. The result of queue system with 2 runways

\begin{tabular}{|c|c|c|c|c|c|c|}
\hline \multirow{2}{*}{$\begin{array}{c}\text { TIME } \\
\text { PERIODE }\end{array}$} & \multicolumn{5}{|c|}{ The result of queue system } \\
\cline { 2 - 6 } & Po & Lq & Ls & Wq & Ws & \\
\hline $1: 00-1: 59$ & 0,07 & 5,1 & 6,83 & 0,07 & 0,1 & \\
\hline $3: 00-3: 59$ & 0,03 & 13,81 & 15,68 & 0,18 & 0,21 \\
\hline $4: 00-4: 59$ & 0,05 & 7,8 & 9,6 & 0.11 & 0,13 & \multirow{3}{*}{$89 \%$} \\
\hline $8: 00-8: 59$ & 0,03 & 13,81 & 15,68 & 0,18 & 0,21 & \\
\hline $9: 00-9: 59$ & 0,05 & 7,8 & 9,6 & 0.11 & 0,13 & \\
\hline $11: 00-11: 59$ & 0,06 & 6,69 & 8,47 & 0,09 & 0,12 & \\
\hline
\end{tabular}

From table 3, the researchers analyzed that peak hours in SHIA happened at 3:00 UTC and 8:00 UTC where at its average time the aircraft queue (Lq) is 13,81 aircraft (14 aircraft). Also from table above, it can be seen that the 
average time of aircraft queue is 0,18 hours/ (Wq). This proves that speed of speed service is non-optimal.

Table 4. The result of queue system with 3 runways

\begin{tabular}{|c|c|c|c|c|c|c|}
\hline TIME & \multicolumn{6}{|c|}{ The result of queue system } \\
\cline { 2 - 6 } PERIODE & Po & Lq & Ls & Wq & Ws & $\rho$ \\
\hline $1: 00-1: 59$ & 0,16 & 0,44 & 2,17 & 0 & 0,03 & \\
\hline $3: 00-3: 59$ & 0,13 & 0,65 & 2,52 & 0 & 0,03 & \\
\hline $4: 00-4: 59$ & 0,15 & 0,54 & 2,34 & 0 & 0,03 & \multirow{5}{*}{$59 \%$} \\
\hline $8: 00-8: 59$ & 0,13 & 0,65 & 2,52 & 0 & 0,03 & \\
\hline $9: 00-9: 59$ & 0,15 & 0,54 & 2,34 & 0 & 0,03 & \\
\hline $11: 00-11: 59$ & 0,15 & 0,5 & 2,28 & 0 & 0,03 & \\
\hline
\end{tabular}

From table 4 it is analyzed if there is a new runway, $/ 3^{\text {rd }}$ runway at SHIA, the service time is getting quick. There is a significant decrease of aircraft service time (Ws) in peak time from 0,21 minutes to 0,03 minutes. Adding new runway is effective to reduce queue of service time (Ws). This plan also affects average time spent by customers or unit for waiting in queue (Wq) becomes 0 queue which means optimal.

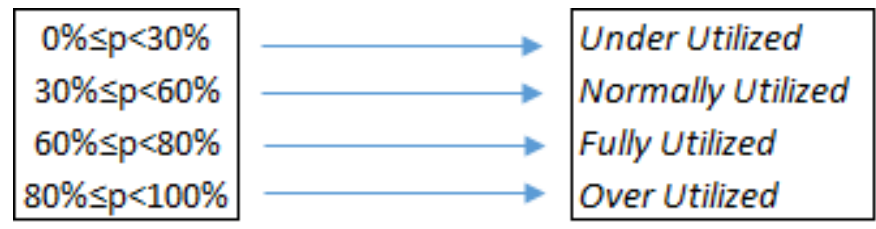

Figure 4. Facility Utlization Category

Source : (unctad, 2014)

From data above it can be concluded that SHIA $\rho$ uses 2 runways the result of $\rho=89 \%$, which means utilization in over utilized condition, but when analyzed using 3 runways the result of $\rho=59 \%$, meaning that runway capacity/utilization is in normally utilized condition. The result proves that SHIA should finish the $3^{\text {rd }}$ runway to reach $\rho=59 \%$.

\section{Conclusion}

Adding new runway is critical action that should be done by PT. Angkasa Pura II to face traffic growth at Soekarno-Hatta International Airport. Now $\rho$ calculation using 2 runways at SHIA is on the level of over utilization condition which is $\rho=89 \%$, when the $3^{\text {rd }}$ runway is finished it will reduce $\rho$ significantly. $\rho$ decreasing becomes $59 \%$. 
Forecasting done by authors has predicted the new runway should be built and ready to operate before MAY 2021 because the traffic movement per hour will reach 91 movements. Without this development, the airport will lose the opportunity income from this traffic growth. Adding new runway is not only about serving and providing airlines to do take-off and landing, but also it will help Indonesia develop the country economy.

This result of the paper encourages PT Angkasa Pura II to build a new runway ( $3^{\text {rd }}$ runway of SHIA) with the purpose to handle many movement per hour in the next 5 years, PT Angkasa Pura II should concern about the facilities and infrastructure like parking stand, gate, the distance of aircraft to terminal, etc that it can be reduced and avoid delay as a problem, accumulation of aircraft movement stacking.

\section{References}

Airnav Indonesia. (2017). Data Operasi. Jakarta.

ATFM. (2015). Chronos atfm. Retrieved from http://chronos.atfm.co.id/

Heizer, J. and B. R. (2009). Operation Management. (D. S. dan I. Almahdy, Ed.) (7th ed.). Jakarta: Salemba Empat.

IATA. (2011). IATA Worldwide Scheduling Guidelines (8th ed.). IATA.

Jakarta Air Traffic Service Center (JATSC). (2017). Peak Hours. Retrieved from http://180.250.88.181/pro_data

Ricardianto, P., \& Rifni, M. (n.d.). Aerodrome Safety for Manouvering Area in Soekarno-Hatta International Airport Cengkareng, 2(3).

River, U. S. (2004). Multi-Channel, Single-Phase. Retrieved from http://summerdietsthatwork.tk/single-server-and-multi-server-waitingline-models-338277.html

Satiti, Y. J. (2012). Pengembangan model..., Yanuar Jinu Satiti, FTUI, 2012.

Setiawan, I., Jakarta, M., \& Majid, S. A. (n.d.). Airport Factor in Flight Delays in Indonesia, 2(3).

Tanjung, M. dan. (2003). Manajemen Produksi dan Operasi (Revisi). Jakarta: Fakultas Ekonomi Universitas Jakarta.

unctad. (2014). United Nations Conference on Trade and Development. Retrieved from http://unctad.org/en/Pages/Home.aspx

Yuliana, D. (2015). Jurnal Perhubungan Udara Strategi Pengembangan Pelayanan Publik di Bandar Udara Internasional Soekarno Hatta Cengkareng Development Strategy for Public Services at The Soekarno Hatta International Airport - Cengkareng, 181-200. 